Ole Øivind Søberg $\emptyset$ konomisjef/prosjektlede Sykehusapotekene HF,

Jan Magne Linnsund, avdelingsoverlege Mottagelsesavd Ullevål universitetssykehus,

Anne Dyvesveen, avdelingssjef varesalg prof, Ullevål

sykehusapotek

Per W Johansen, klinisk farmakolog Klinisk kjemisk avd., Ullevål universitetssykehus

Nina Kristoffersen, nestleder varesalg prof, Ullevål syke-

husapotek

Harald Platou, jurist/sekretariatsleder Legemiddelkomiteen, Ullevål universitetssykehus

\section{Søkeord:}

) Legemiddel

) Medisinhåndtering

) Administrasjon

) Sikkerhet

\title{
Tryggere håndtering av medisiner
}

\author{
Elektronisk legemiddelkabinett ga økt kvalitet i legemiddelhåndteringen.
}

$\mathbf{P}$ rosjekt «effektiv legemiddelforsyning» (ELF) ble etablert våren 2006 som et samarbeidsprosjekt mellom Sykehusapotekene HF, Ullevål universitetssykehus (UUS) og Ullevål sykehusapotek. Prosjektets mål var å fremme forslag til mer effektive og rasjonelle løsninger for legemiddelforsyning til sykehus.

\section{Bakgrunn}

Prosjektet satte opp en hypotese om at «forbedring og effektivisering av de ulike ledd i forsyningskjeden for legemidler og relaterte produkter, vil gi økt kvalitet og sikkerhet i legemiddelhåndteringen, økt leveringsdyktighet til sykehuspost eller -avdeling og bedre legemiddeløkonomi».

Innenfor rammen av en total vurdering av forsyningskjeden for legemidler til sykehus ble det etablert flere delprosjekter. Resultatene i denne delen av prosjektet omhandler utprøving av elektronisk legemiddelkabinett og er i totalprosjektet sammenholdt med resultater fra andre tiltak for å effektivisere forsyningskjeden. De øvrige delprosjektene omhandler standardisering av legemiddellager, elektronisk rekvirering og direkteleveranse fra grossist.

Både i USA og Europa er elektroniske medikamentskap aksepterte løsninger som blir brukt i stadig større grad, særlig for lagring av A- og B-preparater. Prosjektet tok derfor kontakt med aktuelle leverandører av kabinett for å prøve ut dette konseptet i Norge.

Hovedmålsettingen var å prøve ut og kartlegge effekter og konsekvenser av innføring av elektronisk legemiddelkabinett $\mathrm{i}$ mottakelsesavdelingen og sykehusapoteket samt vurdere kostnadsog nytteeffekter. Som delmål ønsket vi å se på konsekvenser for forsyningskjeden, prosedyrer knyttet til legemiddelhåndtering, tidsbruk og kartlegging av prosesser, kapitalbinding, ukurans eller retur, kassasjon, svinn eller feil på lagerbeholdning, servicegrad, leveringsdyktighet og resting, produktutvalg, medikamentutvalg, pasientsikkerhet (hendelser eller avvik) og muligheter for forbedring.

\section{Prosesser og metode}

Mottakelsesavdelingen har ikke et eget sentralt medisinrom, men medikamenter oppbevares på flere pasientundersøkelsesrom og lagerrom. På akuttrommene finnes bakker med medikamenter som brukes ved hjertestans og intubering.

I forkant av utprøvingen ble legemiddelhåndteringsrutinene i avdelingen gjennomgått og nødvendige prosedyrer, retningslinjer og delegasjoner for prosjektperioden utarbeidet. Medikamentutvalgslisten ble revidert og godkjent.

I utprøvingsperioden overtok sykehusapoteket ansvaret for bestilling og påfylling av legemidler. Lister med hva som var blitt fylt på kabinettet ble sendt avdelingsoverlegen for ettergodkjenning.

Kun sykepleiere og hjelpepleiere fikk tilgang til å ta ut legemidler fra kabinettet. Farmasøyter og teknikere fra sykehusapoteket fikk nødvendig tilgang til blant annet påfylling av legemidler.

\section{Innhold i kabinettet}

En ny basisliste med alle nødvendige medikamenter (i alt 175 produktnavn) ble utarbeidet i samarbeid med sykehusapoteket. Medikamentlisten ble supplert med plassering i kabinettet med ønskelige maksimum og minimumsverdier. Kabinettet ble konfigurert med såkalte «minidrawers», «cubies», «matrix»-skuffer og karuseller, som er skuffer som i ulik grad begrenset tilgangen til å ta ut flere preparater enn det som var angitt.

Minimumsbeholdningen måtte være så stor at den varte i tre døgn slik at det ikke var behov for etterfylling i løpet av en helg. Maksimumsbeholdningen ble vurdert ut fra forventet forbruk, plassforhold i kabinettet, holdbarhet og med den kliniske erfaringen som et viktig supplement.

Kabinettet vi fikk til utprøving hadde klare begrensninger, og det optimale hadde vært flere skuffer med høyere sikkerhetsnivå. Etter en omfattende kartlegging av mål og volum på medisinforpakningene ble det utarbeidet en konfigurasjon av kabinettet. A-preparater ble lagt i miniskuffer med en ampulle i hver, slik at sykepleierne kun fikk tilgang til det antallet ampuller som de $ø$ nsket å ta ut. Alle varer på medisinbestillingslisten ble plassert i kabinettet og et tilhørende kjøleskap for medisiner som trenger kald lagring. Låsen til kjøleskapet ble styrt gjennom kabinettet.

Akuttmedisiner måtte være tilgjengelig på akuttrommene og de samme medikamentene ble beholdt utenfor kabinettet i egne bakker til intubering og hjertestans som tidligere. Dessuten ble det laget ytterligere en akuttkoffert med samme innhold som i bakkene.

\section{It-utfordringer}

Kabinettet ble forsøkt integrert med sykehusets pasientadministrative system, men dette viste seg å være problematisk. Da overføringen av pasientdata ikke fungerte optimalt, måtte man legge inn pasientdata manuelt, og dette var tidkrevende. Noe av 


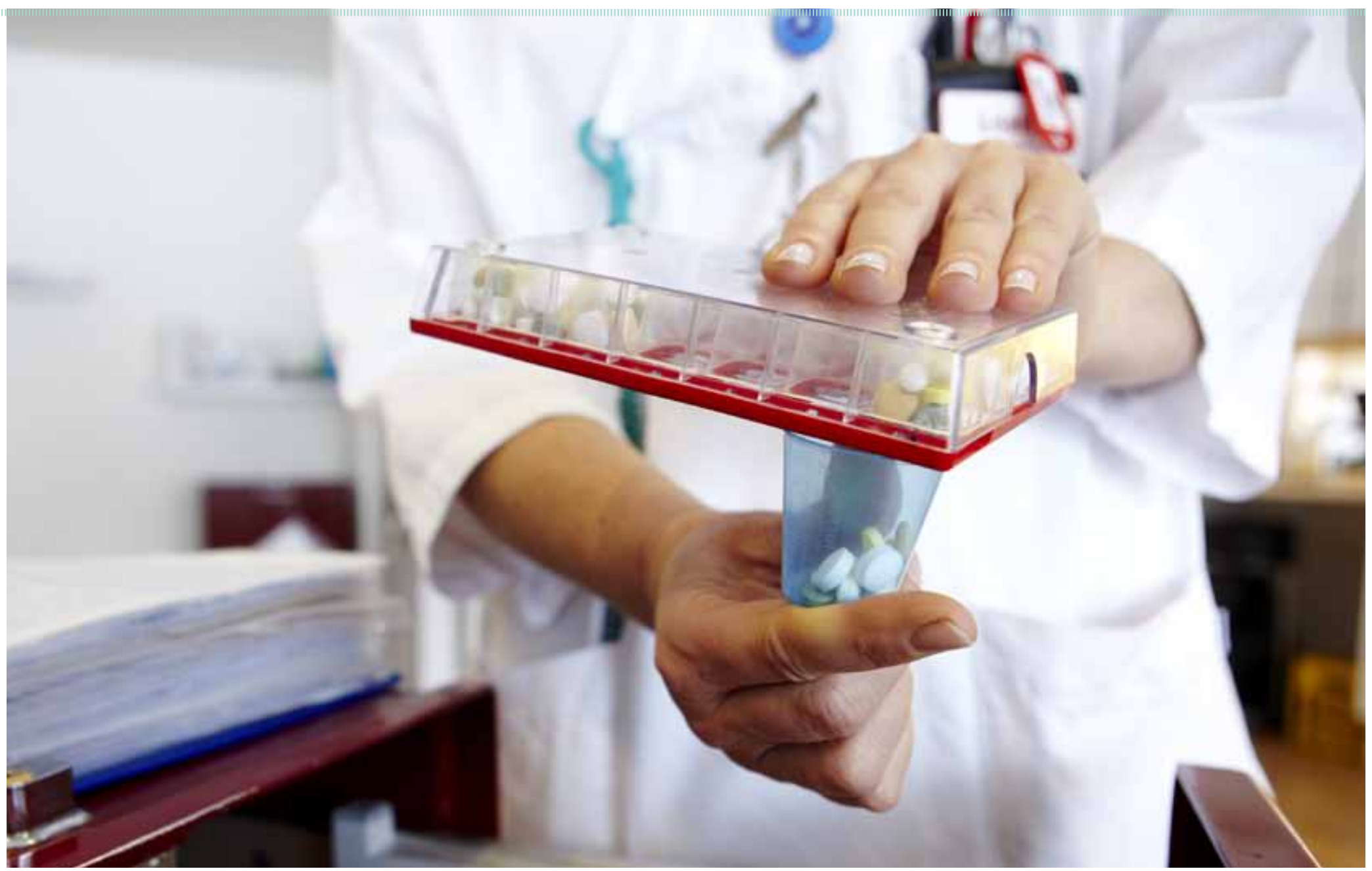

ФKT SIKKERHET: Overgang fra manuell medikamenthåndtering til elektronisk legemiddelkabinett ga bedre sikkerhet mot urettmessige uttak og misbruk av legemidler. Foto: Erik M. Sundt.

problemet var knyttet til at sykehusapoteket og sykehuset har atskilte it-systemer. Tilgangen på tvers av It-systemene var viktig for at sykehusapoteket kunne ha kontroll over medikamenter, bestillingslister, brukere og så videre. Med en permanent installasjon vil kommunikasjon mellom it-systemene løses, noe som vil gi sikrere sporbarhet til pasient, og redusert tidsbruk.

\section{Påfylling}

Sykehusapoteket hadde direkte tilgang til innholdet i kabinettet og skrev ut påfyllingslister for legemidler når disse kom under anbefalt minimumsnivå. Kabinettet ble fylt opp av apotektekniker. Farmasøyt kontrollerte det som ble bestilt på vanlig måte. Vi fors $ø$ kte å fylle opp kabinettet i en periode på dagen med forventet lav pasientaktivitet, men det var umulig å unngå samtidighetsproblem når kabinettet var plassert i et pasientrom og dette virket forstyrrende på apotekteknikerne.

Påfyllingsleddet i kabinettet ble tidlig identifisert som et svakt punkt når det gjelder sikkerhet og kontroll. Her måtte apotektekniker plukke frem riktig legemiddel og legge det på rett plass i kabinettet, noe som krever stor konsentrasjon og nøyaktighet. Det var heller ikke dobbeltkontroll for påfylling av narkotika.

Sykehusapoteket overtok kontrollen med narkotikaregnskapet i kabinettet i prøveperioden. Kabinettet krever vitne når Apreparater skal kontrolltelles. Ved alle slags avvik vil meldinger vise hvem som har logget seg inn, hvilken pasient det er tatt ut medisiner til og hvilke medikamenter, med angivelse av antall og konsentrasjon, som er tatt ut.

Hver gang man fylte på et legemiddel måtte man bekrefte det antallet enheter som lå der fra før. Dette førte til at saldo i kabinettet ble oppdatert kontinuerlig. Det var overraskende mange avvik i saldo ved påfylling. Etter at antall påfylte enheter var bekreftet ble man bedt om å skrive inn den eldste holdbarhetsdatoen. Der- med fikk sykehusapoteket en god oversikt over hvilke medisiner som gikk ut på dato og dette gjorde holdbarhetskontrollen lettere.

\section{Måleparametere}

Før utprøving av kabinettet målte vi den tiden sykepleiere i mottakelsesavdelingen brukte på legemiddelhåndteringen fordelt på telling av A-preparater og narkotikaregnskap, medisinbestilling og på plassetting av medisiner. Under utprøvingen av kabinettet brukte vi ikke tid på månedlig regnskap for A-preparater, da uttak ble loggført elektronisk.

Det ble gjort casestudier over hvor lang tid man brukte på å ta ut medikamenter til noen av de hyppigste pasient- og diagnosegruppene, som for eksempel hjerteinfarkt til akutt stentbehandling (PCI), fractura colli femoris (FCF), hjertestans og KOLS med pneumoni.

Før utprøvingen hadde vi en brukertilfredshetsundersøkelse om samarbeidet med sykehusapoteket om legemiddelhåndteringen $\mathrm{i}$ avdelingen. Undersøkelsen besto av spørsmål og utsagn med seks

\section{Ved påfylling har det ofte voert oppdaget avvik.}

mulige avkryssingsalternativer på hver. Etter utprøvingen ble det gjennomført en ny brukertilfredshetsundersøkelse. De fleste spørsmålene fra det forrige skjemaet var like aktuelle, men det ble lagt til nye spørsmål som omhandlet utprøvingen av kabinettet. Det ble også foretatt tidsmålinger i forhold til bestilling og ekspedisjon på sykehusapoteket. Tiden ble målt fra man skrev ut bestillingsforslaget til apotektekniker var tilbake på apoteket etter påfylling av kabinettet. 
Legemiddellageret i mottakelsesavdelingen ble telt før kabinettet ble tatt i bruk og ved avslutning av prosjektet. Disse tellingene dannet grunnlag for beregning av kapitalbinding. Forbruket $\mathrm{i}$ utprøvingsperioden ble også sammenlignet med tilsvarende periode foregående år.

\section{Resultater}

\section{Tidsstudier}

Før utprøvingsperioden brukte to sykepleiere i gjennomsnitt fire minutter hvert døgn på å telle A-preparatbeholdningen. Medisinbestilling tok gjennomsnittlig 25 minutter hver gang. Å sette på plass medisinene tok gjennomsnittlig 15 minutter for en sykepleier hver gang. Sykepleierne med spesielt ansvar for medikamentbeholdningen brukte 30 minutter på å kontrolltelle A-preparatene og 60 minutter på å gjennomgå A-preparatuttakene og gjøre ferdig regnskapet. Under utprøvingen telte to av prosjektsykepleierne A-preparatene første dag i hver måned og dette tok fem til ti minutter. Daglig telling av Oxynorm tok ett til to minutter.

To caser for akutt PCI viste at tidsbruken til medikamentuttak økte i utprøvingsperioden og at det var mindre variasjon i tidsbruken om pasienten lå på resusciteringsrommet i forhold til et vanlig undersøkelsesrom. I case A lå pasienten på rom 6 (lengst unna medikamentkabinettet) som ikke har medikamenter på rommet, mens pasienten i case B lå på resusciteringsrommet hvor det er medisiner. Gjennomsnittlig tok det 40 sekunder mer

\section{Det har blitt enklere å finne rett medikament.}

å hente medisiner i case A i forhold til case B før utprøvingen. I utprøvningsperioden tok det lengre tid å finne medikamentene $\mathrm{i}$ begge casene med henholdsvis 51 sekunder på rom 6 og 52 sekunder lengre tid på resusciteringsrommet.

Case viste at for pasient med FCF (lårhalsbrudd) på rom 1 brukte en gjennomsnittlig 35 sekunder mer på å hente medikamenter i utprøvingsperioden med kabinettet. Case for KOLS-pasient med pneumoni på rom 4 viste at tidsbruken økte med 31 sekunder for henting av medikamenter i utprøvingsperioden. Case for hjertestans på resusciteringsrommet viste at det her tok 62 sek lengre tid å hente medikamenter under utprøvingsperioden.

\section{Brukertilfredshet}

Undersøkelsen ga en klar oppfatning om at det var tilnærmet like lett å finne rett medikament med kabinettet som før prøveperioden uten kabinett. Samtidig var det lettere å finne synonympreparater under utprøvingen av kabinettet. Det var også en entydig oppfatning at plasseringen av medisinkabinettet var uheldig $\mathrm{i}$ utprøvingsperioden, og at det hadde vært mer hensiktsmessig å plassere kabinettet utenom pasientrom og helst sentralt plassert i nærheten av koordinatorskranken.

Når det gjelder spesifikt bruken av kabinettet mente de fleste at det både var enkelt og raskt å logge seg på og at det var lett å bruke kabinettet. Det var mer delte oppfatninger om hvor raskt det var å bruke legemiddelkabinettet og dette er jo i samsvar med tidsmålingene.

Et klart flertall sier at de administrerte medisiner mer effektivt med kabinettet. De tingene som ble best likt med legemiddelkabinettet kan oppsummeres slik:

, Positivt å slippe medisinbestilling, påfylling og rydde på plass medisiner

, Mindre kapitalbinding
, Enklere å finne rett medikament og synonympreparater.

, Alle medisinene finnes på samme sted

\ Kvalitetsforbedring og bedre kontroll på forbruk og behov for påfyll, enklere påfyll. (Vi får de medisinene vi skal ha i de kvanta som er forhåndsdefinert, går ikke tom for medisiner, lite rot på rommene med medisiner, enkel narkotikakontroll, mindre rot og «vedlikehold», bedre oversikt, sikkerhet og kvalitetssikring.) , Kabinettet er driftssikkert uten nedetid, raskt å logge på, enkelt å bruke og at man slipper å gå rundt med nøkler til medisinskapene

De tingene man likte dårligst med kabinettet var:

, Manglende overføring av pasientdata

I Problemer med påloggingen/skanning av fingeravtrykket

, Man opplever å bruke lang tid når noe haster. Man må fylle ut pasientdata selv og så vente på at skuffene åpner seg når man skal ta ut flere medikamenter samtidig

, Stressende at man ikke kunne ta ut flere medikamenter på en gang

, Det er lett å trykke på feil medikament, vanlig fysiologisk saltvann $(\mathrm{NaCl})$ må tas ut gjennom kabinettet, det er lett å ta feil i antibiotikaskuffen, vi må gå fra dårlige pasienter for å hente medisiner, og det blir vanskelig å ta ut medikamenter for å ha i beredskap til akuttpasienter fordi returskuffen er liten

En stor andel ønsker flere medisiner plassert i akuttskrin på behandlingsrommene enn det som var tilfelle i utprøvingsperioden. Det gjaldt særlig Atrovent og Ventoline, men også Nitrospray, Afipran, Dispril, $\mathrm{NaCl}$ og Xylocain er nevnt. I tillegg foreslås å etablere «akuttbakker» til hjerte- og KOLS-pasienter samt etablere en egen utvidet akuttboks.

\section{Sykehusapoteket}

Sykehusapoteket brukte gjennomsnittlig 20 minutter per bestilling før utprøvingsperioden, etter innføring av kabinett utgjorde tiden 112 minutter og dette gir en økning i tid per bestilling på cirka 92 minutter. Dette forklares med at sykehusapoteket har overtatt mange arbeidsoppgaver som påfylling, håndtering av returer og holdbarhetsdatoer. I tillegg hadde sykehusapoteket etablert et eget tilleggslager for mottakelsesavdelingen som ble brukt til påfylling av kabinettet, noe som medførte ekstra tidsbruk.

\section{Kostnads- og nytteeffekt}

Legemiddelforbruket i utprøvingsperioden ble beregnet til å utgjøre kr. 167 051, sammenlignet med kr. 145351 i tilsvarende periode året før, og er altså cirka kr. 21000 høyere. Dette kan skyldes variabler utenom selve kabinettet. Kapitalbindingen av lageret ved oppstart ble beregnet til kr. 86 821. Verdien av varer når kabinettet var maksimalt oppfylt utgjorde kr. 72 997. Reduksjon i kapitalbinding utgjør dermed i overkant av 16 prosent. Videre må man påregne at kabinettet eliminerer retur til sykehusapoteket på grunn av feilbestilling og lagersanering, noe som vil utgjøre en besparelse for avdelingen på cirka kr. 12000 per år med utgangspunkt i gjennomsnittstall for sykehuset.

\section{Urettmessig uttak}

Når medikamentene ligger i et legemiddelkabinett, medfører det en høyere terskel for urettmessige uttak av medikamenter. Kabinettet gir sporbarhet til hvem som logger seg på kabinettet og hvilke medikamentskuffer vedkommende har tilgang til. I skuffene med størst sikkerhet gir dette også sporing av antall 
uttak på enkeltpreparater. Når medisinuttak knyttes til pasient, gjør det et mulig urettmessig uttak svært synlig.

\section{Oppsummering}

Tidsbruk

Målingene av tidsbruk på å hente medisiner til pasienter i de fem definerte casene, viste oss at det gjennomsnittlig tok noe lenger tid å ta ut medisiner fra kabinettet, uten at dette ansees som kritisk. Man bør ta tidsbruken med i vurderingen om hvor den beste plasseringen av et permanent kabinett skal være. Det bør også tas i betraktning at med økt bruk og kjennskap til kabinettet, bør man kunne forvente en viss reduksjon i tidsbruk sammenlignet med de målinger man gjorde.

Det var tidsbesparende under utprøvingen av kabinettet at vi slapp å gå gjennom hvert uttak til hver pasient den aktuelle måneden. Også fordi sykepleierne slapp å bruke tid på å bestille og sette på plass medisiner. Det var ikke noe tid å spare på den daglige A-preparatkontrollen, men noe tid ble spart på den månedlige A-preparatkontrollen.

\section{Ukurans}

Problemet med ukurans er nærmest ikke-eksisterende med et medisinkabinett, fordi kabinettet fylles opp fra sykehusapoteket ut fra medikamentutvalg og forhåndsdefinerte minimums- og maksimumsgrenser. I avdelingen ble det ikke foretatt noen kassasjoner på grunn av holdbarheten i prøveperioden da farmasøyt eller apotektekniker sjekker dette ved påfylling.

Ved påfylling har det ofte vært oppdaget avvik. Noen ganger har dette skyldtes at det har vært lagt inn feil enhet, for eksempel esker i stedet for ampuller. Andre ganger har det vært reelt svinn. Det må sies at de fleste av disse avvikene er på ufarlige medisiner og sier noe om at de kanskje på grunn av sin beskaffenhet burde vært holdt utenom kabinettet. Kun en gang under utprøvingsperioden ble det oppdaget kritisk feil på lagerbeholdningen da Ketorax og Afipran var byttet om.

\section{Levering}

I prøveperioden har avdelingen hatt hyppig og god kontakt med sykehusapoteket og det er blitt etablert gode relasjoner som både avdeling og sykehusapotek har hatt nytte av. Konklusjonene i spørreundersøkelsene er klare på at man i utprøvingsperioden har sett gevinsten ved et tett og nært samarbeid med sykehusapoteket.

\section{Medikamentutvalg}

Rundt 175 medikamenter fikk plass i kabinettet. Kun en gang ble det problemer ved at man gikk tom for et spesielt medikament. Dette skjedde på grunn av opphopning av pasienter som spesifikt trengte dette medikamentet. I utprøvingsperioden ble det uttrykt $ø$ nsker om å flytte flere medikamenter fra kabinettet til undersøkelsesrommene, men det ble ikke gitt etter for slike ønsker.

\section{Brukervennlighet}

Vi fikk et godt inntrykk av brukervennligheten under tidsbrukstestene da vi sto og observerte ved kabinettet. Noen hadde problemer med selve påloggingen samt enkelte brukerfeil. Det var av og til et problem med kø foran kabinettet, men dette har vi jo erfart også foran våre vanlige medisinskap.

I utprøvingsperioden opplevde vi at det ble atskillig roligere å ta imot og behandle pasienter på akuttrommene, idet det var minimalt med forstyrrelser fra pleiere som skulle hente medisiner til andre pasienter. Ulempen har vært at pleierne på akuttrommene måtte gå ut fra behandlingsrommet for å hente medisiner utover akuttmedisinene. Både sykepleiere og leger har gitt uttrykk for at det har vært uvanlig og føltes litt utrygt. Løsningen ville sannsynligvis være flere akuttmedisiner som for eksempel Abbodop inne på akuttrommene.

Det ble oppfattet som lite brukervennlig at skuffene i kabinettet åpner seg mot deg. Du må stå nær kabinettet for å taste og blir «dyttet» eller hindrer at skuffen får åpnet seg om du ikke flytter deg raskt til siden. Loggen viser at noen pleiere har en lav prosent med vellykkede pålogginger, mens mange har 99-100 prosent suksess ved pålogging.

\section{Pasientsikkerhet}

I utprøvingsperioden har medisinkabinettet vist seg driftssikkert. Det oppsto to kritiske hendelser i utprøvingsperioden. En gang «frøs» hele systemet og det var ikke mulig å komme seg videre eller å få logget seg ut. Problemet ble løst ved å slå av hele systemet. Da det ble startet igjen, fungerte alt som normalt. Den andre kritiske hendelsen oppsto da «failed drawer»-ikonet kom frem på skjermen. Når man forsøkte å løse problemet kom det melding om manglende rettigheter. Problemet skyldtes antakeligvis at forrige bruker ikke hadde lukket lokket på «cubien» før skuffen ble lukket, og dermed låste hele skuffen seg.

Det har vært enkelt å finne medikamentene. Muligheten for å tilpasse brukeroppsettet ved å søke opp medikamenter etter generisk navn eller merkenavnet har vært brukervennlig. For nye sykepleiere i avdelingen og for ekstravakter har det blitt enklere å finne rett medikament.

\section{Konklusjon}

Den vesentlige gevinsten for avdelingen i utprøvingsperioden var $ø k t$ kvalitet i medikamenthåndteringen. For de medikamentene som var plassert i miniskuffer og «cubier», var vi sikre på å få ut medikamentet med rett konsentrasjonen og administrasjonsform, under forutsetning av at påfyllingen var korrekt utført. Når det gjaldt matrix-skuffene måtte vi fremdeles sjekke både medikamentnavn og styrke nøye. Avdelingen ønsker å ha flest mulige medikamenter i miniskuffer. Miniskuffer er den enheten med størst grad av sikkerhet.

Kabinettet og påloggingsrutinene gir kontroll over hvem som har logget seg på, hva de har gjort og hva de har tatt ut til den enkelte pasient. Kabinettet ga noe økt tidsbruk til henting av medisiner, men forskjellene var små og man forventer at dette utlignes ved en lengre utprøvingsperiode. Plasseringen av kabinettet $\mathrm{i}$ mottakelsesavdelingen var ikke optimal og heller ikke konfigurasjonen av selve kabinettet. Dette hadde å gjøre med klare fysiske begrensninger i lokalet og at vi ikke kunne velge fritt i forhold til hvilket kabinett vi kunne prøve ut. Hvis man skulle gå inn i en permanent løsning med et medikamentkabinett, måtte disse elementene være på plass på forhånd og dermed bidra til en bedre totalløsning enn det som var mulig å prøve ut i vårt prosjekt.

Kabinettet gir betydelig bedre sikkerhet mot urettmessige uttak og misbruk av legemidler. En kabinettløsning åpner også for en interessant diskusjon rundt eierforholdene til de medisinene som ligger i kabinettet. Med et kabinett kan sykehusapoteket fakturere på grunnlag av det som faktisk tas ut fra kabinettet.

Ved å sammenstille disse observasjonene om legemiddelkabinettet med konklusjonene i hovedprosjektets øvrige delprosjekter, ser vi at vi får en større effekt av de enkelte tiltakene hvis de gjennomføres samlet enn om de gjennomføres hver for seg. Flere tiltak for å effektivisere legemiddelforsyningskjeden henger tett sammen. Eksempel på dette er standardisering av legemiddelsortimentet i en basisliste, som legges til grunn for konfigurering av et elektronisk legemiddelkabinett. IIII 